\title{
Air Pollution and Allergic Rhinitis: Role in Symptom Exacerbation and Strategies for Management
}

This article was published in the following Dove Press journal:

Journal of Asthma and Allergy

\author{
Carmen $\mathrm{H} \mathrm{Li}\left(\mathbb{D}^{1,2}\right.$ \\ Kyle Sayeau ${ }^{1,2}$ \\ Anne K Ellis (1D) ${ }^{1-3}$ \\ 'Department of Biomedical and \\ Molecular Sciences, Queen's University, \\ Kingston, ON, Canada; ${ }^{2}$ Allergy Research \\ Unit, Kingston Health Sciences Center - \\ KGH Site, Kingston, ON, Canada; \\ ${ }^{3}$ Department of Medicine, Queen's \\ University, Kingston, ON, Canada
}

Correspondence: Anne K Ellis

$\mathrm{Tel}+$ I 613-548-2336

$\mathrm{Fax}+1$ 613-546-3079

Email ellisa@queensu.ca

\begin{abstract}
This article reviews the current understanding of the role of air pollution in both the symptom exacerbation and rising prevalence of allergic rhinitis (AR) for the development of future AR therapeutics and management strategies. We discuss the epidemiological evidence for this relationship through birth cohort studies, the economic impact of AR, and the influence of air pollution through the lens of the exposome framework of allergic disease development. This is followed by a discussion on the influence of diesel exhaust and diesel exhaust particles (DEP) from motor vehicle emissions and their implication in the rising prevalence of allergic disease and allergic sensitization through triggering inflammatory signalling pathways that exacerbate AR symptoms. Finally, a summary is provided of clinical trials assessing the influence of air pollution on AR with a depiction of currently available therapies and management strategies. Future directions in the development of AR modalities given the air pollution-mediated symptom exacerbation are challenged with unfolding the complex gene-environment interaction product of heterogenous AR presentation.
\end{abstract}

Keywords: diesel exhaust, particulate matter, therapy, vehicle emissions

\section{Introduction}

Allergic rhinitis (AR) is a non-communicable, IgE-mediated inflammatory disease caused by type 1 hypersensitivity reactions induced by allergen exposure with common symptomology including rhinorrhea, itching, sneezing, bronchial hyperresponsiveness, or airflow obstruction. ${ }^{1,2}$ Due to the nature of AR symptoms, the condition is often ignored, misdiagnosed, and thought not to be overly detrimental, yet AR amasses substantial socioeconomic burden, adverse effects on sleep length and quality, productivity, and quality of life. ${ }^{3}$ AR prevalence has been cited to be approximately $10-30 \%$ of adult populations, though the true incidence might be indeterminable as data collection necessitates physician diagnosis and does not account for individuals who self-medicate or are undiagnosed. ${ }^{4,5}$ Given the rising prevalence of allergic respiratory disease over the last several decades and increasing air pollution with urbanization, industrialization, and rapid economic growth, there has been longstanding interest in the association between AR development and air pollution. Furthermore, environmental factors influencing AR treatment and management strategies have garnered interest; specifically, the management of allergic rhinitis in urban environments with significant levels of air pollution being a growing focus in the research community. By 2050, it is predicted that $68 \%$ of the world's population will be living in urban centres. ${ }^{6}$ Consequently, urban 
outdoor air pollution is responsible for 4.2 million deaths worldwide each year and is observed to increase the risk of developing respiratory conditions including AR, asthma, and chronic obstructive pulmonary disease. ${ }^{7}$

Air pollution refers to substances emitted by processes and sources such as fuel combustion, power generators, industrial facilities, or agricultural waste sites in the ambient air, which may take the form of solid particulate matter (PM), liquid, or gaseous emissions. A substantial environmental contribution to the prevalence of allergic disease has been recognized, ${ }^{8}$ where both symptom exacerbation and allergic disease development may result from exposure to air pollution contents, namely gaseous compounds including $\mathrm{NO}_{2}$, $\mathrm{NO}, \mathrm{SO}_{2}, \mathrm{CO}$, and $\mathrm{CO}_{2}$, and airborne PM from traffic diesel exhaust particles (DEP). Diesel exhaust particles are a solid agglomeration of carbonaceous material with volatile organic and sulfurous compounds emitted directly by diesel engine fuel combustion with various particle sizes. DEP particle size displays a trimodal distribution, where nanoparticles of $<50 \mathrm{~nm}$ represent the vast majority of particles emitted, ${ }^{9}$ and $\mathrm{PM}_{10}$ of diameter $<10 \mathrm{~mm}$, fine particles of $\mathrm{PM}_{2.5}$ with diameter $<2.5 \mathrm{~mm}$, and ultrafine particles of $\mathrm{PM}_{0.1}$ with diameter $<0.1 \mathrm{~mm}$ being the most common $\mathrm{PM}$ sizes in the traffic-related air pollutant (TRAP) group. ${ }^{10} \mathrm{DEP}$ particle size governs its relative implication in allergic disease exacerbation given the respective particle's diameter where $\mathrm{PM}_{10}$ can reach the lower respiratory tract, $\mathrm{PM}_{2.5}$ may penetrate the lungs, and PM of diameter $<1.0 \mathrm{~mm}$ can penetrate further into the alveoli and thus reach the bloodstream. ${ }^{11}$ Given the rising burden of air pollutionassociated AR, there is currently an ongoing challenge of understanding AR development and the role of air pollution in both symptom exacerbation and the rising prevalence of allergic diseases. Understanding the interaction of environmental exposures like air pollution with the genetic landscape of allergic disease development is critical to the formulation of future therapeutic modalities.

\section{Epidemiology}

AR prevalence is estimated at $10-30 \%$ of adults in the United States and Europe, reported as the most frequent atopic disease in developed countries with up to $40 \%$ incidence in children. ${ }^{12}$ These values exhibit discordance between epidemiological studies of varying sizes, ${ }^{13}$ possibly due to methodological disparities between positive allergy testing and self-reported allergy. Larger studies including the Swiss Study on Air Pollution and Lung Disease in Adults (SAPALDIA) and The National Health and Nutrition Examination Surveys (NHANES) found that self-reported allergy tends to overpredict $A R$ incidence, ${ }^{13,14}$ that epidemiological analysis is markedly varied amongst different populations of individuals and the geographic location studied. AR further complicates study results by numerous phenotypic and endotypic presentations with categorization into seasonal AR, perennial $\mathrm{AR}$, and mixed rhinitis. Additional complexity is conferred due to the nature of the allergic disease being a product of the interaction between genetic predisposition, epigenetics, and environmental exposure contributing to the heterogeneity of AR presentation.

$\mathrm{AR}$ incidence has been increasing in most industrialized countries of the world with rapid urbanization, linked to increasing air pollution in both symptom exacerbation and the rising prevalence of atopy. Given AR commonality in developed countries, there is substantial socioeconomic burden and associated co-morbidities impacting quality of life with facilitation of both presenteeism and absenteeism, representing $76 \%$ to $93 \%$ of total AR costs in a 2005 to 2015 study assessing AR and work productivity. ${ }^{15}$ Further, that AR symptoms impact sleep quality with increased sleep disturbances given moderate and severe AR, perpetuating daytime sleepiness and ability to work along with depression, anxiety, and impaired cognitive function. ${ }^{16}$ $80 \%$ of AR patients develop symptoms before the age of $20,{ }^{17}$ where $\mathrm{AR}$ is estimated to generate $\$ 2$ to $\$ 5$ billion annually in direct health-related cost expenditures including $\$ 2$ to $\$ 4$ billion in lost annual productivity in the United States alone. ${ }^{18}$

Recently, various experimental and epidemiologic studies have well demonstrated this association between air pollution, particularly PM, and the rising prevalence of allergic diseases. ${ }^{19,20}$ Air pollution can be classified as part of the exposome, a measure of all the exposures of a subject in their lifetime, and how they influence health. $\mathrm{AR}$, as a complex gene-environment interaction product, has been described through a framework called the exposome, with three separate domains: internal, specific external, and general external. ${ }^{21}$ The internal domain consists of innate host-related factors including metabolism, microbiome, epigenetics, and age, whereas the general external exposures include the larger socioeconomic, geographic, and psychological factors. ${ }^{21}$ Most relevantly, the last domain encompasses individual-level specific external exposures, including cigarette smoke and air pollution. The exposome thus represents a point of analysis, where exposome examination through birth cohort studies 
represents an avenue to better appreciate the environmental contribution to allergic disease development.

Current ongoing studies investigating the exposome include the Canadian Healthy Infant Longitudinal Development (CHILD) birth cohort study, which aims to address the developmental origins of allergy, in which environmental exposures in both pre-natal and postnatal life influence susceptibility to allergy development through epigenetic mechanisms. ${ }^{8}$ The study recruited over 3500 pregnant women, who gave birth between 2009 and 2012 and examines early-life, human, genetic, epigenetic, and microbiome data through biological samples, questionnaires, and home and clinical assessments. ${ }^{8}$ Comparably, the Kingston Allergy Birth Cohort (KABC) compliments the CHILD study, which found a significant correlation among both pre-natal and postnatal factors, including socioeconomic status, housing type, urban residence, and garage type. ${ }^{26}$ The study recruited mothers in their 2 nd and 3rd trimesters of pregnancy and used assessments of psychosocial characteristics, household exposures, birth characteristics, nutrition, and biological samples of blood, urine, nasal swabs, stool, and breast milk. Overall, the study found that the general external domain acted as a critical modifier of the specific external domain with a significant association between caesarean section, gestational age, and older siblings with decreased respiratory reports. ${ }^{26}$ Further, the cohort found a negative association between gestational age and respiratory symptom risk, consistent with pre-term children studies on lung function, where allergic disease incidence was associated with prenatal smoke exposure, mold, and air freshener usage. ${ }^{26}$

In conjunction with some of the findings in the KABC study, exposure to airborne PM and other air pollutants has been implicated in several pre-natal and childhood exposure studies suggest that the timing of exposure or cumulative exposure to specific pollutants may uniquely influence allergic disease development. A 2016 study by Deng et al surveyed exposure to air pollutants during pregnancies to assess the risk of childhood atopic diseases. The study, which surveyed 2598 preschool children, found that maternal exposure to $\mathrm{NO}_{2}$ during the third semester was associated with children's lifetime incidence of allergic rhinitis. ${ }^{22}$ AR prevalence was found to be significantly positively correlated with age-related accumulative $\mathrm{PM}_{10}$, $\mathrm{SO}_{2}$, and $\mathrm{NO}_{2}$ exposure in preschool children, but not associated with site-specific background concentrations of pollutants. ${ }^{23}$ Furthermore, Norbäck et al (2019) found that postnatal exposure to $\mathrm{NO}_{2}$ and $\mathrm{PM}_{10}$ is associated with an increased prevalence and lower remission of childhood allergic rhinitis. ${ }^{24}$ Notably, a similar epidemiological study which collected data on PM sources, antibiotics use, ambient temperature and ambient air pollution found that $\mathrm{PM}_{10}$ exposure can synergistically enhance risk factors, such as antibiotics and environmental tobacco smoke, for childhood allergic rhinitis. $^{25}$

\section{Mechanisms of Diesel Exhaust Particles and Allergic Rhinitis}

Diesel exhaust particles (DEPs) act as adjuvants, augmenting the immune response to aeroallergens associated with allergic rhinitis (AR) through numerous mechanisms. DEP enhances IgE production when co-administered intranasally with ovalbumin in mice, ${ }^{27,28}$ and when immunized with pollen grains and DEP in a rat pollen model. ${ }^{29}$ The polycyclic aromatic hydrocarbon (PAH) components of DEP enhance basophil activation in individuals with birch pollen allergy with IL-4, a Th2 developmental cytokine, and IL- 8 secretion, ${ }^{30}$ a granulocyte chemoattractant with a role in human lung IgE-mediated lung inflammation. $^{31}$ In a sequence of articles, Diaz-Sanchez et al demonstrated that DEP can augment mast cell degranulation of histamine alone or subsequent to antigenFCeRI engagement, and can promote de novo mucosal $\mathrm{IgE}$ response to an allergen in individuals without previous sensitization, suggesting an adjuvant role in enhancing $\operatorname{IgE}$ response to neoantigens. ${ }^{32}$ This has led to a more comprehensive understanding of DEP's role in driving allergic sensitization. DEP enhances antigen presentation through the upregulation of HLA-DR and CD86 expression in cultured nasal epithelial cells, ${ }^{33}$ cell-surface molecules typically restricted to antigen-presenting cells, contributing to the enhancement of allergic reactions through upregulation of these co-stimulatory signals involved in T-cell activation and survival. Further, nasal fibroblasts increase expression of IL-6 and IL-8 through activation of p38, Akt, and NF-kB signalling pathways, aggravating allergic rhinitis through promoting local nasal inflammation. ${ }^{34}$ Epithelial cells play a key role in allergic inflammation with upregulated expression of intercellular adhesion molecules ICAM-1 and VCAM-1, critical in cell-cell attachment for $\mathrm{T}$ cell activation, consequently increased with the presence of DEP in bronchiolar epithelium. ${ }^{35}$ The nasal epithelial barrier acts as the primary physiological barrier against paracellular allergen invasion, maintained by apical tight junctions (TJ) between epithelial 
cells which are disrupted in individuals with nasal allergy. DEP disrupts tight junctions to increase the paracellular permeability of allergens in vivo through downregulation of zonula occludens- 1 and claudin- 1 transmembrane TJ protein expression, independent of the transcriptional regulation of TJ constituents. ${ }^{36}$ DEP accomplishes TJ disruption through a reactive oxygen species (ROS)-mediated pathway, where ROS production by nasal epithelial cells mediates DEP-induced TJ disruption lasting for several days with a single DEP treatment. ${ }^{36}$ In bronchiolar epithelium, ROS was generated by DEP component metabolism including PAH and quinones, resulting in MAPK signal transduction pathway and NF-kB transactivation-induced release of proinflammatory cytokines with nuclear translocation of the Nrf2 transcription factor for antioxidant protein-encoding genes. ${ }^{37}$ DEPs thus trigger numerous signalling pathways that lead to an enhanced inflammatory response through ROS generation that exacerbates allergic rhinitis.

\section{Recent Studies and Current Treatments}

AR management and therapies aim to prevent or reduce symptoms associated with allergic inflammation. With the increasing levels of air pollution and epidemiological studies displaying a relationship between air pollutants and exacerbation of allergic/respiratory symptoms, it may be increasingly appropriate for AR treatments to be assessed under environmental conditions mimicking outdoor air pollution. ${ }^{20,38}$ Several studies investigate the mechanisms that contribute to exacerbated AR symptoms and the efficacy of medications (Table 1). In these studies, AR or nonatopic subjects are commonly exposed to DE or DEP via a controlled allergen exposure facility, pollution chamber, intranasal challenge, or breathing apparatus. Combined DEP and allergen exposure was found to exacerbate AR symptoms relative to sole allergen exposure. ${ }^{39}$ Currently, fexofenadine hydrochloride is the only medication that has been tested in a controlled allergen exposure facility to alleviate AR symptoms during DEP and allergen co-exposure. ${ }^{39} \mathrm{DE}$ and allergen coexposure negatively impacts lung function, increases CD4, IL-4, CD138, and nasal elastase in the respiratory submucosa of AR subjects; increases in blood neutrophils (24 hours) and eosinophils (24 and 48 hours) postexposure were also found. ${ }^{39,40}$ Additionally, co-exposure to allergen and DE alters the expression of allergen- induced secreted proteins linked to the protein phosphatase 2A pathway and the MAPK1-ERK1/3 axis, which regulates the response to oxidative stress and inflammation, respectively. ${ }^{41}$ Other forms of air pollutant exposure include oil fly ash, a particulate produced from coal combustion. Hauser et al (2003) found increased nasal lavage leukocytes, neutrophils, and IL-4 in AR subjects coexposed to an allergen and residual oil fly ash. ${ }^{42}$ Coexposure with allergen and atmospheric levels of ozone resulted in elevated nasal lavage neutrophils, eosinophils, and mononuclear cells. ${ }^{43}$ Extended co-exposure with nitrogen dioxide $\left(\mathrm{NO}_{2}\right)$ elevated levels of eosinophilic cationic protein in nasal lavage fluid. ${ }^{44}$

Surveying the results of these trials, a number of considerations should be noted. An investigative study suggests that the order and timing of exposure may be an important differentiation when comparing results. Clifford et al (2016) found that allergen and DE co-exposure was not associated with significant changes in DNA methylation in bronchial epithelial cells. However, exposure to allergen and DE separated by four weeks resulted in methylation changes in over $500 \mathrm{CpG}$ sites, which differed depending on the order of exposure. ${ }^{45}$ Besides alterations in DNA methylation, there may be other lingering effects in subjects due to $\mathrm{DE}$ or allergen exposure prior to a study or between study visits.

Exposure to DEP versus DE and the gas composition of DE is another differentiator. The toxicity and depth of deposition of DEP in the lungs is dependent on its size, which may be affected if the study methods involve the collection and re-aerosolization of DEP. ${ }^{46-48}$ The most numerous and most toxic particles fall into the fine $\left(\mathrm{PM}_{2.5}\right)$ and ultrafine $\left(\mathrm{PM}_{0.1}\right)$ range. ${ }^{48} \mathrm{DEP}$ forms aggregates when stored in a bulk source, which may make their atmosphere particle size distribution difficult to replicate during aerosolization. ${ }^{48}$ Lastly, the use of DE treatments or high-efficiency particulate absorbing (HEPA) filters, which are commonly installed in automobiles and some breathing apparatuses, may be relevant to study design. In Wooding et al (2019), HEPA filters reduced $\mathrm{PM}_{2.5} 94 \%$ and VOCs $9.5 \%$, while increasing $\mathrm{NO}_{2}$ content $350 \%$ in DE. Electrostatic precipitation in HEPA filters oxidizes nitrous oxide (NO), thereby increasing the levels of $\mathrm{NO}_{2}$ in DE. Instead of alleviating the exacerbated $\mathrm{AR}$ symptoms expected from co-exposure studies, lung function was further impaired compared to DE and allergen coexposure. The impairment in lung function is partially attributed to elevated $\mathrm{NO}_{2}$, which is consistent with other 
Table I Summary of Interventional and Investigative Studies Assessing Air Pollution and Allergen Exposure in Subjects with Allergic Rhinitis

\begin{tabular}{|c|c|c|c|c|}
\hline Identifier & Study Type & Patients & Exposure & Results \\
\hline \multicolumn{5}{|c|}{ Air Pollution Particulate and Diesel Exhaust Particle Exposure } \\
\hline $\begin{array}{l}\text { Ellis et al } \\
2019^{39}\end{array}$ & $\begin{array}{l}\text { Phase } 3 \text {, single-center, } \\
\text { sequential and parallel- } \\
\text { group, double-blind, } \\
\text { randomized study }\end{array}$ & $\begin{array}{l}257 \text { adults with } \\
\text { allergic rhinitis }\end{array}$ & $\begin{array}{l}\text { DEP }\left(600 \pm 100 \mathrm{ng} \cdot \mathrm{m}^{-3}\right) \text {, } \\
\text { Ragweed pollen }(3500 \pm \\
\left.500 \text { grains. }^{-3}\right), \\
\text { Allegra }^{\circledR} / \text { Telfast }^{\circledR} \\
\text { (Fexofenadine } \\
\text { Hydrochloride) } 180 \mathrm{mg}\end{array}$ & $\begin{array}{l}\text { Allegra }{ }^{\circledR} / \text { Telfast }{ }^{\circledR} 180 \mathrm{mg} \text { significantly decreased } \\
\text { pollution-exacerbated AR symptoms by } 21 \%(\mathrm{p}= \\
0.0 \mathrm{I} 48 \text { ) in adult allergic rhinitis patients. Exposure } \\
\text { to combined ragweed and DEP significantly } \\
\text { increased TNSS }(p<0.000 \mathrm{I}) \text {. }\end{array}$ \\
\hline $\begin{array}{l}\text { Hauser et al } \\
2003^{42}\end{array}$ & $\begin{array}{l}\text { Randomized, crossover, } \\
\text { exposure study }\end{array}$ & $\begin{array}{l}5 \text { adults with } \\
\text { allergic rhinitis } \\
3 \text { adults } \\
\text { nonatopic } \\
\text { subjects }\end{array}$ & $\begin{array}{l}\text { Residual fly ash particulate* } \\
\left(1.00 \mathrm{mg} \cdot \mathrm{m}^{-3}\right) \text {, Ragweed } \\
\text { pollen, Birch pollen, Oak } \\
\text { pollen }\end{array}$ & $\begin{array}{l}\text { A I } 43 \% \text { and } 130 \% \text { enhancement of nasal lavage } \\
\text { leukocytes and neutrophils, respectively, were } \\
\text { found in atopic but not in nonatopic subjects } \\
\text { exposed to particulate and allergen. No significant } \\
\text { enhancement in IL-3, TNF- } \alpha \text {, or total lgE in group } \\
\text { of subjects during exposures. }\end{array}$ \\
\hline \multicolumn{5}{|c|}{ Diesel Exhaust Exposure } \\
\hline $\begin{array}{l}\text { Clifford et al } \\
2017^{45}\end{array}$ & $\begin{array}{l}\text { Randomized, crossover, } \\
\text { exposure study }\end{array}$ & $\begin{array}{l}17 \text { adults with } \\
\text { allergic rhinitis }\end{array}$ & $\begin{array}{l}\text { DE }\left(300 \mu \mathrm{g} \cdot \mathrm{m}^{-3}\right) \\
\text { House dust mite, Timothy/ } \\
\text { Pacific grass pollen, } \\
\text { Birch pollen }\end{array}$ & $\begin{array}{l}\text { Exposure to an allergen and DE separated by } 4 \\
\text { weeks resulted in significant changes in more } \\
\text { than } 500 \mathrm{CPG} \text { sites } 48 \text { hours post-exposure. } \\
\text { Sites of differential methylation differed } \\
\text { depending on the order of exposure. Analysis } \\
\text { of differentially methylated CPG sites identified } \\
\text { genes for transcriptional factor activity, protein } \\
\text { metabolism, cell adhesion, and vascular } \\
\text { development. }\end{array}$ \\
\hline $\begin{array}{l}\text { Hosseini } \\
\text { et al } 2016^{52}\end{array}$ & $\begin{array}{l}\text { Blinded, crossover, } \\
\text { exposure study }\end{array}$ & $\begin{array}{l}12 \text { adults with } \\
\text { allergic rhinitis }\end{array}$ & $\begin{array}{l}\text { DE }\left(300 \mu g \cdot \mathrm{m}^{-3}\right) \\
\text { House dust mite, } \\
\text { Pacific grass pollen, } \\
\text { Birch pollen }\end{array}$ & $\begin{array}{l}\text { Allergen-DE co-exposure resulted in significantly } \\
\text { elevated CD4, IL-4, CDI } 38 \text {, and neutrophil } \\
\text { elastase in the respiratory submucosa of atopic } \\
\text { subjects compared to filtered air and saline } \\
\text { exposure. }\end{array}$ \\
\hline $\begin{array}{l}\text { Mookherjee } \\
\text { et al } 2018^{41}\end{array}$ & $\begin{array}{l}\text { Randomised, blinded, } \\
\text { crossover, exposure study }\end{array}$ & $\begin{array}{l}14 \text { adults with } \\
\text { allergic rhinitis }\end{array}$ & $\begin{array}{l}\text { DE }\left(300 \mu g \cdot m^{-3}\right) \\
\text { House dust mite, } \\
\text { Pacific grass pollen, } \\
\text { Birch pollen }\end{array}$ & $\begin{array}{l}\text { Protein changes in the lungs unique to allergen- } \\
\text { DE co-exposure include the significantly } \\
\text { enhanced ( } \geq 16 \text {-fold) production of cystatin-SA, } \\
\text { complement C4B, lipocalin-I, mucin- } 16 \text {, and } \\
\text { transcobalamin-I compared to allergen-filtered- } \\
\text { air exposure. }\end{array}$ \\
\hline $\begin{array}{l}\text { Wooding } \\
\text { et al } 2019^{40}\end{array}$ & $\begin{array}{l}\text { Randomized, double-blind, } \\
\text { crossover, exposure study }\end{array}$ & $\begin{array}{l}14 \text { adults with } \\
\text { allergic rhinitis }\end{array}$ & $\begin{array}{l}\text { DE }\left(300 \mu g \cdot \mathrm{m}^{-3}\right) \\
\text { Particle depleted diesel } \\
\text { exhaust, } \\
\text { House dust mite, } \\
\text { Pacific grass pollen, } \\
\text { Birch pollen }\end{array}$ & 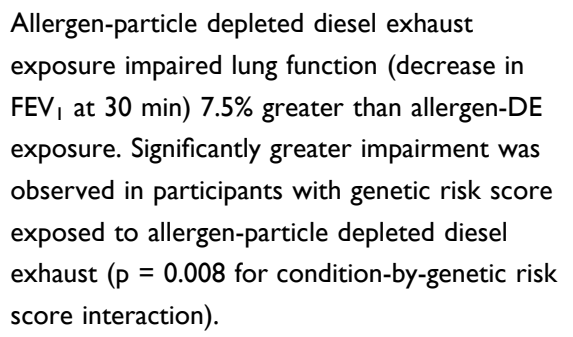 \\
\hline
\end{tabular}

(Continued) 
Table I (Continued).

\begin{tabular}{|l|l|l|l|l|}
\hline Identifier & Study Type & Patients & Exposure & \multicolumn{2}{l|}{ Results } \\
\hline Gaseous Air Pollutant Exposure & allergic rhinitis \\
\hline $\begin{array}{l}\text { Bascom et al } \\
1990^{43}\end{array}$ & $\begin{array}{l}\text { Randomized, crossover, } \\
\text { exposure study }\end{array}$ & $\begin{array}{l}12 \text { adults with } \\
\text { Ragweed pollen, } \\
\text { Grass pollen }\end{array}$ & $\begin{array}{l}\text { Ozone } 0.5 \mathrm{ppm}), \\
\text { increase in upper and lower respiratory symptoms, } \\
\text { a 7-fold increase in nasal lavage neutrophils, a 20-fold } \\
\text { increase in eosinophils, a 10-fold increase in } \\
\text { mononuclear cells, and a significant increase in nasal } \\
\text { albumin concentration compared to clean air and } \\
\text { allergen exposure. }\end{array}$ \\
\hline $\begin{array}{l}\text { Wang et al } \\
1995^{44}\end{array}$ & $\begin{array}{l}\text { Randomized, single-blind, } \\
\text { crossover study }\end{array}$ & $\begin{array}{l}16 \text { adults with } \\
\text { allergic rhinitis }\end{array}$ & $\begin{array}{l}\text { Nitrogen dioxide (400 ppb), } \\
\text { Grass pollen (mixed) }\end{array}$ & $\begin{array}{l}\text { Allergen challenge after exposure to Nitrogen } \\
\text { dioxide but not air, significantly increased levels of } \\
\text { only eosinophil cationic protein in nasal lavage } \\
\text { fluid (p<0.05). }\end{array}$ \\
\hline
\end{tabular}

Note: *Coal combustion product.

Abbreviations: DE, diesel exhaust; DEP, diesel exhaust particles; TNSS, Total Nasal Symptom Score.

studies demonstrating that $\mathrm{NO}_{2}$ can enhance airway response to an allergen, but a definite cause is unclear. ${ }^{40,49}$

\section{Management of Allergic Rhinitis Exacerbated by Air Pollution}

The first-line treatment of AR includes oral or nasal corticosteroids and avoidance of allergens and irritants such as tobacco smoke, moulds, and DE. Pollen exposure can be reduced by closing windows, window screens, and avoidance of parks during peak pollen seasons. Air pollution exposure can be reduced by avoiding rush hours and avoiding time outdoors during the afternoon of summer months when ground-level ozone levels are highest. ${ }^{50}$ Outdoor air pollution and allergen exposure in the workplace may be mitigated by shift rotations, personal protective equipment, and adjusted working hours. Following avoidance and corticosteroids, secondline therapies include decongestants, cromolyn, $\mathrm{H}_{1}$ antihistamines, leukotriene receptor antagonists, and allergen immunotherapy. ${ }^{51}$ Fexofenadine hydrochloride $\left(\right.$ Allegra ${ }^{\circledR}$ ) is an oral non-sedating antihistamine; the $180 \mathrm{mg}$ dose has been verified to alleviate AR symptoms aggravated by diesel exhaust particulates. ${ }^{39}$ Since there are no specific indicators that differentiate AR aggravated by air pollution, and few targeted AR medications for combined exposure, education to improve awareness of air pollution may be advisable. Avoidance of peak commuting hours in combination with peak pollen season may be recommended to individuals living in areas with high levels of air pollution.
Further clinical trials and studies are needed to determine more effective methods of mitigating pollutionexacerbated AR symptoms. While designing future studies, there are a variety of air pollutant constituents, allergens, and exposure methods. For example, DE produced by different engines have variable levels of PM and gas composition. Re-aerosolization during exposure to PM may replicate outdoor particulate distributions with relative success. ${ }^{48} \mathrm{~A}$ simultaneous pollutant and allergen exposure may be possible if a pollution chamber or controlled allergen challenge facility is available but may otherwise be delivered via a breathing apparatus. The availability of exposure facilities may also dictate whether a subject with AR is exposed to an allergen and pollutants simultaneously, or after one another. Future studies may be designed to improve understanding of the priming effect exposure to DE, DEP, or allergen has on subsequent exposure to air pollutants and allergens. Interventional studies may also investigate whether medications are effective at alleviating exacerbated AR symptoms during co-exposure to $\mathrm{O}_{3}, \mathrm{NO}_{2}$, or DE with elevated DEP levels.

\section{Conclusion}

Allergen and air pollutant co-exposure have been shown to exacerbate AR symptoms and induce changes in the allergic immune response relative to sole allergen or air pollution exposure. Epidemiological and investigative studies demonstrate the immunological effects from allergen and air pollutant co-exposure, which include exacerbated AR symptoms and enhanced inflammatory response with the 
recruitment of inflammatory cells, cytokines, and interleukins. Despite advances in understanding the priming or adjuvant effect of air pollutants, such as DEP, there is a lack of research in potential methods of managing AR exacerbated by air pollution. A survey of clinical trials reveals fexofenadine hydrochloride as the only therapy that has been shown to alleviate exacerbated AR symptoms during pollen and DEP co-exposure. Other investigative clinical trials support the continued evaluation of potential AR therapies during co-exposure and air pollution avoidance in AR symptom management. However, in many instances, complete avoidance of allergens and air pollution is not feasible. Education of subjects with AR and further assessment of current and future AR therapies are needed to establish a complete program to manage AR exacerbated by air pollution exposure.

\section{Acknowledgments}

The authors wish to thank Dr. Anne Ellis for supporting the review and Ms. Sandra McKeown for assistance with the literature search.

\section{Disclosure}

Dr Anne K Ellis reports grants including grant to research institution from Sanofi, Novartis, and Medexus; grants from Regeneron; non-financial support, and in kind supports from ALK Abello; speaker and/or advisory board for AstraZeneca, Aralez, GSK, Mylan, Pfizer, and Pediapharm, outside the submitted work; Dr Ellis is also a member of Rhinitis, Rhinosinusitis and Ocular Allergy Committee, AAAAI. The authors report no other conflicts of interest in this work.

\section{References}

1. Small P, Frenkiel S, Becker A, et al. Rhinitis: a practical and comprehensive approach to assessment and therapy. J Otolaryngol. 2007;36.

2. Bourdin A, Gras D, Vachier I, Chanez P. Upper airway 1: allergic rhinitis and asthma: united disease through epithelial cells. Thorax. 2009;64:999-1004. doi:10.1136/thx.2008.112862

3. Meltzer EO. Allergic rhinitis: burden of illness, quality of life, comorbidities, and control. Immunol Allergy Clin North Am. 2016;36:235-248. doi:10.1016/j.iac.2015.12.002

4. Dykewicz MS, Fineman S, Skoner DP, et al. Diagnosis and management of rhinitis: complete guidelines of the Joint Task Force on practice parameters in allergy, asthma and immunology. American Academy of Allergy, Asthma, and Immunology. Ann Allergy Asthma Immunol. 1998;81:478-518. doi:10.1016/S1081-1206(10)63155-9

5. Keith PK, Desrosiers M, Laister T, Schellenberg RR, Waserman S. The burden of allergic rhinitis (AR) in Canada: perspectives of physicians and patients. Allergy Asthma Clin Immunol. 2012;8:7. doi:10. $1186 / 1710-1492-8-7$
6. Nations U. 2018 Revision of World Urbanization Prospects. United Nations: New York; 2018.

7. Organization WH. Ambient air pollution: a global assessment of exposure and burden of disease. 2016.

8. Subbarao P, Anand SS, Becker AB, et al. The Canadian Healthy Infant Longitudinal Development (CHILD) study: examining developmental origins of allergy and asthma: table 1. Thorax. 2015;70:998-1000. doi:10.1136/thoraxjnl-2015-207246

9. Kittelson DB. Engines and nanoparticles. $J$ Aerosol Sci. 1998;29:575-588. doi:10.1016/S0021-8502(97)10037-4

10. Hassoun Y, James C, Bernstein DI. The effects of air pollution on the development of atopic disease. Clin Rev Allerg Immunol. 2019;57:403-414. doi:10.1007/s12016-019-08730-3

11. Rapiejko P, Jurkiewicz D, Pietruszewska W, Zielnik-Jurkiewicz B, Woroń J, Lipiec A. Treatment strategy of allergic rhinitis in the face of modern world threats. Otolaryngol Pol. 2018;72:1-12. doi:10.5604/01.3001.0011.8057

12. Bousquet J, Schünemann HJ, Samolinski B, et al. Allergic rhinitis and its impact on asthma (ARIA): achievements in 10 years and future needs. $J$ Allerg Clin Immunol. 2012;130:1049-1062. doi:10.1016/j.jaci.2012.07.053

13. Salo PM, Calatroni A, Gergen PJ, et al. Allergy-related outcomes in relation to serum IgE: results from the National Health and Nutrition Examination survey 2005-2006. J Allergy Clin Immunol. 2011;127:1226-1235.e7. doi:10.1016/j.jaci.2010.12. 1106

14. Tschopp JM, Sistek D, Schindler C, et al. Current allergic asthma and rhinitis: diagnostic efficiency of three commonly used atopic markers (IgE, skin prick tests, and Phadiatop ${ }^{\circledR}$ ): results from 8329 randomized adults from the SAPALDIA study. Allergy. 1998;53:608-613. doi:10.1111/j.1398-9995.1998.tb03937.x

15. Vandenplas O, Vinnikov D, Blanc PD, et al. Impact of rhinitis on work productivity: a systematic review. $J$ Allergy Clin Immunol Pract. 2018;6:1274-1286.e9. doi:10.1016/j.jaip.2017.09. 002

16. Dass K, Petrusan AJ, Beaumont J, Zee P, Lai J-S, Fishbein A. Assessment of sleep disturbance in children with allergic rhinitis. Annal Allerg Asthma Immunol. 2017;118:505-506. doi:10.1016/j. anai.2016.12.022

17. Stewart M, Ferguson B, Fromer L. Epidemiology and burden of nasal congestion. Int J Gen Med. 2010;3:37-45. doi:10.2147/ IJGM.S8077

18. Seidman MD, Gurgel RK, Lin SY, et al. Clinical practice guideline: allergic rhinitis. Otolaryngol Head Neck Surg. 2015;152:S1-43. doi:10.1177/0194599814561600

19. Diaz-Sanchez D, Proietti L, Polosa R. Diesel fumes and the rising prevalence of atopy: an urban legend? Curr Allergy Asthma Rep. 2003;3:146-152. doi:10.1007/s11882-003-0027-4

20. Chung H-Y, Hsieh C-J, Tseng -C-C, Yiin L-M. Association between the first occurrence of allergic rhinitis in preschool children and air pollution in Taiwan. Int J Environ Res Public Health. 2016;13:268. doi:10.3390/ijerph 13030268

21. Wild CP. The exposome: from concept to utility. Int $J$ Epidemiol. 2012;41:24-32. doi:10.1093/ije/dyr236

22. Deng Q, Lu C, Li Y, Sundell J, Dan N. Exposure to outdoor air pollution during trimesters of pregnancy and childhood asthma, allergic rhinitis, and eczema. Environ Res. 2016;150:119-127. doi:10.1016/j.envres.2016.05.050

23. Effects of ambient air pollution on allergic rhinitis among preschool children in Changsha, China | springerLink [Internet]. Available from: https://link.springer.com/article/10.1007\%2Fs11434-013-57252. Accessed August 14, 2020.

24. Norbäck D, Lu C, Zhang Y, et al. Onset and remission of childhood wheeze and rhinitis across China - associations with early life indoor and outdoor air pollution. Environ Int. 2019;123:61-69. doi:10.1016/ j.envint.2018.11.033 
25. Norbäck D, Lu C, Zhang Y, et al. Sources of indoor particulate matter (PM) and outdoor air pollution in China in relation to asthma, wheeze, rhinitis and eczema among pre-school children: synergistic effects between antibiotics use and PM10 and second hand smoke. Environ Int. 2019;125:252-260. doi:10.1016/j. envint.2019.01.036

26. North ML, Brook JR, Lee EY, et al. The Kingston allergy birth cohort. Annal Allerg Asthma Immunol. 2017;118:465-473. doi:10.1016/j.anai.2017.01.002

27. Takafuji S, Suzuki S, Koizumi K, et al. Diesel-exhaust particulates inoculated by the intranasal route have an adjuvant activity for $\operatorname{IgE}$ production in mice. J Allergy Clin Immunol. 1987;79:639-645. doi:10.1016/S0091-6749(87)80161-6

28. Heo Y, Saxon A, Hankinson O. Effect of diesel exhaust particles and their components on the allergen-specific IgE and IgG1 response in mice. Toxicology. 2001;159:143-158. doi:10.1016/S0300-483X(00)00418-2

29. Steerenberg PA, Dorm JAMA. A pollen model in the rat for testing adjuvant activity of air pollution components. Inhal Toxicol. 1999;11:1109-1122. doi:10.1080/089583799196619

30. Lubitz S, Schober W, Pusch G, et al. Polycyclic aromatic hydrocarbons from diesel emissions exert proallergic effects in birch pollen allergic individuals through enhanced mediator release from basophils. Environ Toxicol. 2009;NA:NA. doi:10.1002/tox.20490

31. Erger RA, Casale TB. Interleukin- 8 plays a significant role in IgE-mediated lung inflammation. Eur Respir J. 1998;11:299-305. doi:10.1183/09031936.98.11020299

32. Diaz-Sanchez D, Garcia MP, Wang M, Jyrala M, Saxon A. Nasal challenge with diesel exhaust particles can induce sensitization to a neoallergen in the human mucosa. $J$ Allerg Clin Immunol. 1999;104:1183-1188. doi:10.1016/S0091-6749(99)70011-4

33. Takizawa R, Pawankar R, Yamagishi S, Takenaka H, Yagi $T$. Increased expression of HLA-DR and CD86 in nasal epithelial cells in allergic rhinitics: antigen presentation to $\mathrm{T}$ cells and up-regulation by diesel exhaust particles. Clin Exp Allergy. 2007;37:420-433. doi:10.1111/j.1365-2222.2007.02672.x

34. Kim JA, Cho JH, Park I-H, Shin J-M, Lee S-A, Lee H-M. Diesel exhaust particles upregulate interleukins IL-6 and IL-8 in nasal fibroblasts. PLoS One. 2016;11:e0157058. doi:10.1371/journal. pone. 0157058

35. Salvi S, Blomberg A, Rudell B, et al. Acute inflammatory responses in the airways and peripheral blood after short-term exposure to diesel exhaust in healthy human volunteers. $\mathrm{Am}$ J Respir Crit Care Med. 1999;159:702-709. doi:10.1164/ajrccm. 159.3.9709083

36. Fukuoka A, Matsushita K, Morikawa T, Takano H, Yoshimoto T. Diesel exhaust particles exacerbate allergic rhinitis in mice by disrupting the nasal epithelial barrier. Clin Exp Allergy. 2016;46:142-152. doi:10.1111/cea.12597

37. Baulig A, Garlatti M, Bonvallot V, et al. Involvement of reactive oxygen species in the metabolic pathways triggered by diesel exhaust particles in human airway epithelial cells. Am J Physiol Lung Cell Mol Physiol. 2003;285:L671-9. doi:10.1152/ajplung.00419.2002

38. Heinrich J, Wichmann H-E. Traffic related pollutants in Europe and their effect on allergic disease. Curr Opin Allergy Clin Immunol. 2004;4:341-348. doi:10.1097/00130832-200410000-00003
39. Ellis AK, Murrieta-Aguttes M, Furey S, Picard P, Carlsten C. Efficacy and safety of fexofenadine hydrochloride for the treatment of allergic rhinitis symptoms aggravated by pollutants: a phase 3 , double-blind, placebo-controlled, randomised study. Double-Blind, Placebo-Controlled, Randomised Study (11/21/2019). 2019

40. Wooding DJ, Ryu MH, Hüls A, et al. Particle depletion does not remediate acute effects of traffic-related air pollution and allergen. A randomized, double-blind crossover study. Am J Respir Crit Care Med. 2019;200:565-574. doi:10.1164/rccm.201809-1657OC

41. Mookherjee N, Piyadasa H, Ryu MH, et al. Inhaled diesel exhaust alters the allergen-induced bronchial secretome in humans. European respiratory journal [Internet]; 2018. Available from: https://erj.ersjour nals.com/content/51/1/1701385. Accessed August 14, 2020.

42. Hauser R, Rice TM, Krishna Murthy GG, et al. The upper airway response to pollen is enhanced by exposure to combustion particulates: a pilot human experimental challenge study. Environ Health Perspect. 2003;111:472-477. doi:10.1289/ehp.5862

43. Bascom R, Naclerio RM, Fitzgerald TK, Kagey-Sobotka A, Proud D. Effect of ozone inhalation on the response to nasal challenge with antigen of allergic subjects. Am Rev Respir Dis. 1990;142:594-601. doi:10.1164/ajrccm/142.3.594

44. Wang JH, Devalia JL, Duddle JM, Hamilton SA, Davies RJ. Effect of six-hour exposure to nitrogen dioxide on early-phase nasal response to allergen challenge in patients with a history of seasonal allergic rhinitis. J Allerg Clin Immunol. 1995;96:669-676. doi:10.1016/ S0091-6749(95)70266-0

45. Clifford RL, Jones MJ, MacIsaac JL, et al. Inhalation of diesel exhaust and allergen alters human bronchial epithelium DNA methylation. $J$ Allerg Clin Immunol. 2017;139:112-121. doi:10.1016/j.jaci.2016.03.046

46. International Commission on Radiological Protection. ICRP Publication; 1988.

47. Raftis JB, Miller MR. Nanoparticle translocation and multi-organ toxicity: a particularly small problem. Nano Today. 2019;26:8-12. doi:10.1016/j.nantod.2019.03.010

48. Cooney DJ, Hickey AJ. The generation of diesel exhaust particle aerosols from a bulk source in an aerodynamic size range similar to atmospheric particles. Int $J$ Nanomedicine. 2008;3:435-449. doi:10.2147/IJN.S1193

49. Strand V, Rak S, Svartengren M, Bylin G. Nitrogen dioxide exposure enhances asthmatic reaction to inhaled allergen in subjects with asthma. Am $J$ Respir Crit Care Med. 1997;155:881-887. doi:10.1164/ajrccm.155.3.9117021

50. Zuurbier M, Hoek G, Oldenwening M, Meliefste K, van den Hazel P, Brunekreef B. Respiratory effects of commuters' exposure to air pollution in traffic. Epidemiology. 2011;22:219-227. doi:10.1097/ EDE.0b013e3182093693

51. Wheatley LM, Togias A, Solomon CG. Clinical practice. Allergic rhinitis. N Engl J Med. 2015;372:456-463. doi:10.1056/NEJMcp1412282

52. Hosseini A, Hirota JA, Hackett TL, McNagny KM, Wilson SJ, Carlsten C. Morphometric analysis of inflammation in bronchial biopsies following exposure to inhaled diesel exhaust and allergen challenge in atopic subjects. Part Fibre Toxicol. 2016;13:2. doi:10.1186/s12989-016-0114-z

\section{Publish your work in this journal}

The Journal of Asthma and Allergy is an international, peer-reviewed open-access journal publishing original research, reports, editorials and commentaries on the following topics: Asthma; Pulmonary physiology; Asthma related clinical health; Clinical immunology and the immunological basis of disease; Pharmacological interventions and new therapies. The manuscript management system is completely online and includes a very quick and fair peer-review system, which is all easy to use. Visit http://www.dovepress.com/testimonials.php to read real quotes from published authors. 